\title{
OBITUARY
}

\section{Prof. I. A. Preece}

Pror. I. A. Preece, who died suddenly at the age of fifty-seven on August 12 while on holiday in Switzerland, was a leading figure in the world of brewing science. Born in Birmingham in 1907, he graduated at the University of Birmingham in 1927 and was later awarded the degree of D.Sc. (Birmingham) in 1950. Meanwhile, following three years on the staff of the Department of Biochemistry in Birmingham, he was successively lecturer (1931-45), head of the Department of Brewing (1950) and professor in the Department of Brewing and Applied Biochemistry (1950-64) in the Heriot-Watt College, Edinburgh.

Prof. Preece found in brewing, and particularly in malting, a fertile field for his early and abiding interests in plant biochemistry. Structural problems in connexion with the carbohydrates of barley and of malt led him to undertake with exemplary precision work on numerous difficult topics such as the hemicelluloses and phytin, on the nature and function of the amylases, and on proteolytic and cytolytic enzymes. None of these subjects would attract anyone easily repulsed by difficulties, for all abounded in preparative and analytical problems. Nevertheless, many of Preece's papers, especially those dealing with the cytases, phosphatases and amylases of germinat- ing barley, are clearly destined to become indispensable to future advances. His interests extended, however, far beyond his personal research. Prof. Preece was a gifted teacher, as evidenced by his postgraduate students, who came from many parts of the world, and by many audiences at home and abroad, who knew him as an expert lecturer whose lectures were, quite apart from their invariably substantial scientific content, always memorable for their lucidity and nice distinction of language.

Among many professional and educational activities, Prof. Preece played a prominent part in the Royal Institute of Chemistry and the Institute of Brewing. He had since 1949 been editor of the Journal of the Institute of Brewing, the high quality of which over recent years owes much to his meticulous standards. Prof. Preece was elected a Fellow of the Royal Society of Edinburgh in 1949 and early in 1964 was awarded the Horace Brown Medal as the highest honour which the Institute of Brewing could bestow. Perhaps, however, his most effective memorial is to be found in the large number of brewers whom he trained. Preece probably more than anyone else, at least in the English-speaking world, inspired them with the possibilities of scientific understanding and control in what is in some respects still a markedly traditional industry.
A. H. CoOK

\section{NEWS and VIEWS}

\section{The Royal Society: Officers for 1964}

Ar the Anniversary Meeting held on November 30, Sir Howard Florey, Provost of The Queen's College, Oxford, and formerly professor of pathology in the Univorsity of Oxford, was ro-elected president of the Royal Society. The other officers re-elected for the ensuing year were: Treasurer, Lord Fleck, formerly chairman of Imperial Chemical Industries, Ltd.; Physical Secretary, Sir William Hodge, Master of Pembroke College and Lowndean professor of astronomy and geometry in the University of Cambridge; Biological Secretary, Prof. A. A. Miles, director of the Lister Institute and professor of experimental pathology in the University of London; IForeign Secretary, Sir Patrick Iinstead, Rector of the Imperial College of Science and Technology. The other members of Council olected (or re-elected, marked *) were: Sir Eric Ashby, Master of Clare College, Cambridge; Prof. D. H. R. Barton, professor of organic chemistry in the Imperial College of Science and Technology; *Prof. P. M. S. Blackett, professor of physics in the Imperial College of Science and Technology; Sir William Cook, deputy chief scientific adviser, Ministry of Defence; *Prof. A. H. Cottrell, Goldsmiths' professor of metallurgy in the University of Cambridge; *Prof. C. A. Coulson, Rouse Ball professor of mathematics in the University of Oxford; Prof. F. S. Dainton, professor of physical chemistry in the University of Leeds; Prof. K. C. Dunham, professor of geology in the Univorsity of Durham; Prof. G. W. Harris, Dr. Lee's professor of anatomy in the University of Oxford; Prof. W. O. James, professor of botany in the Imperial College of Science and Technology; *Prof. B. Katz, professor of biophysics in University College, London; Sir Hans Krebs, Whitley professor of biochemistry in the University of Oxford; Dr. N. Kurti, reader in physies in the University of Oxford, and Senior Research Fellow, Brasenose College; * Sir Bornard Lovell, professor of radio astronomy in the University of Manchoster and director of the Nuffield
Radio Astronomy Laboratories, Jodrell Bank; Prof. K. Mather, professor of genetics in the University of Birmingham and Vice-Chancellor elect of the University of Southampton; *Prof. J. W. S. Pringle, Linacre professor of zoology in the University of Oxford.

\section{Crystallography in the University of Birmingham:}

Prof. A. J. C. Wilson, F.R.S.

Prof. A. J. C. Wilson, at present professor of physics in tho University College of South Wales and Monmouthshire, Cardiff, has been appointed to the newly established chair of crystallography in the Department of Physics in the University of Birmingham. Born and educated in Canada, Prof. Wilson was engaged in research at the Massachusetts Institute of Technology before joining the Cavendish Laboratory, Cambridge; he holds Ph.D. degrees of both the Massachusetts Institute of Technology and the University of Cambridge. In 1945 he movod to University College, Cardiff, and became head of the physies department there in 1954. Prof. Wilson is woll known for his distinguished contributions to $\mathrm{X}$-ray analysis in the olucidation of the atomic structure of crystals. He was elected a Fellow of the Royal Socioty of London in 1963. His now appointment will take effect from October 1, 1965.

\section{Aeronautics and Astronautics in the University of} Southampton: Prof. G. M. Lilley

PRoF. G. M. LILley, who has hold the chair of exporimental fluid mechanics in the Department of Aerodynamics at the College of Aeronautics, Cranficld, since January 1963, has boen appointed to the chair of aeronauties and astronauties at the University of Southampton in succossion to Prof. E. J. Richards, who has recontly been appointed to the new chair of applied acousties and to the directorship of the Institute of Sound and Vibration Research at Southampton. Prof. Lilley, a graduate of the University of London, has boen a resident member of 